\title{
Vitamin D receptor gene Taql and Apal polymorphisms and steroid responsiveness in childhood idiopathic nephrotic syndrome
}

This article was published in the following Dove Press journal: International Journal of Nephrology and Renovascular Disease 5 August 2016

Number of times this article has been viewed

\author{
Amal A Al-Eisa \\ Mohammad Z Haider \\ Department of Pediatrics, Faculty \\ of Medicine, Kuwait University, \\ Safat, Kuwait
}

Correspondence: Amal A Al-Eisa Department of Pediatrics, Faculty of Medicine, Kuwait University, PO Box 24923, Safat I3II0, Kuwait

Tel +96525319486

Fax: +96525338940

Email amal@hsc.edu.kw
Background: Vitamin D activity is controlled by vitamin D receptors (VDRs), which are affected by different genetic polymorphisms, including TaqI and Apal restriction fragment length polymorphisms (RFLPs), which have been reported to be associated with several diseases. The aim of this study was to determine the frequency and the association of VDR gene polymorphisms with idiopathic nephrotic syndrome (INS) and steroid responsiveness in Kuwaiti children.

Subjects and methods: Genotypes of the VDR TaqI gene polymorphism and the Apal gene polymorphism were analyzed using polymerase chain reaction-RFLP in 78 INS patients and 56 matched controls.

Results: A total of 78 INS (62 steroid sensitive [SS] and 16 steroid resistant [SR]) patients with a mean age of $6.5 \pm 3.1$ years were studied. Male:female ratio was $2: 1$. The TT genotype of $V D R-T a q$ I polymorphism was detected in $41 \%$ of the INS patients compared to $42 \%$ of the controls $(P=0.816)$. The heterozygous TC genotype was detected in $33 \%$ of INS patients compared to $46 \%$ of the controls ( $P=0.462)$. The CC genotype was detected in $25.6 \%$ of INS patients and $21 \%$ of the controls $(P=0.719)$. The $\mathrm{C}$-allele frequency, in its homozygous and heterozygous forms, was $71 \%$ in INS patients compared to $63 \%$ in the controls $(P=0.342)$. Similarly, no significant difference was detected in terms of $V D R-A p a l$ polymorphism in INS patients compared to the controls for all the three genotypes ( $P=0.76, P=0.207$, and $P=0.364$, respectively, for GG, GT, and TT genotypes). The T-allele frequency, in its homozygous and heterozygous forms, was $89 \%$ in INS patients compared to $93 \%$ in the controls $(P=0.076)$. No significant difference was found in any of the allele frequencies between SS and SR subgroups when compared with each other or when compared to the controls.

Conclusion: Our data do not support the use of $V D R-T a q \mathrm{I}$ or -Apal gene polymorphisms as genetic markers of INS nor do they predict steroid responsiveness in children with the disease. Keywords: idiopathic nephrotic syndrome, steroid sensitive, steroid resistant, genotype, polymorphism

\section{Background}

Vitamin D is an essential fat-soluble vitamin that plays an important role in skeletal mineralization as well as regulation of secretion of hormones such as insulin, renin, fibroblast growth factor, and parathyroid hormone. ${ }^{1}$

In the cells, vitamin D exerts its effects through the vitamin D receptor (VDR), a nuclear transcription factor to which vitamin $\mathrm{D}$ binds via the carboxyl-terminal ligandbinding domain. The VDR molecule belongs to a large class of nuclear receptors that include thyroid, steroid, and retinoic acid receptors. ${ }^{2,3}$ The gene sequence encoding VDR can vary, resulting in polymorphic forms such as the variants produced on 
digestion with restriction enzymes such as ApaI and TaqI. Some of these polymorphic forms of VDR are associated with reduced effectiveness of vitamin $\mathrm{D}$, which may lead to higher risk and predisposition to various bone and endocrine diseases, such as osteoporosis, rickets, urolithiasis, and diabetes mellitus type $1 .^{4-9}$

The pathogenesis of idiopathic nephrotic syndrome (INS) remains inconclusive and controversial and is considered to be mediated by the immune system and the imbalance between T-helper cell subtype 1 (Th1) and Th2 cytokines, which are in turn regulated by 1,25-dihydroxy D3, which is the active form of vitamin D. Vitamin D exerts its effects through its receptor (VDR), which plays a role in the transcriptional inhibition of cytokine genes, subsequently affecting cytokine release. ${ }^{10}$ Ethnic and genetic differences in the frequencies of the $V D R$ polymorphic genotypes have been previously reported in different populations..$^{9,11,12}$ In this study, we explore the frequency of $V D R$ gene TaqI and ApaI restriction fragment length polymorphisms (RFLPs) in Kuwaiti Arab children with INS and the effect of the different $V D R$ polymorphic genotypes on steroid responsiveness.

\section{Subjects and methods Subjects}

Patients below the age of 12 years with a confirmed diagnosis of INS were included in this study. These patients were referred and evaluated at a specialized pediatric nephrology clinic at Mubarak Al-Kabeer University Hospital over a period of 6 years. Diagnosis of INS was based on the presence of generalized edema, nephrotic-range proteinuria, and hypoalbuminemia with or without hyperlipidemia. Patients were categorized by their initial response to steroid treatment as steroid sensitive (SS) or steroid resistant (SR). Steroid responsiveness was defined as the disappearance of proteinuria (negative to traces in a urine dipstick test for 3 days consecutively) or a urine protein/creatinine level of $<0.2$ within the first 4 -week course of full-dose prednisolone therapy $\left(60 \mathrm{mg} / \mathrm{m}^{2} / \mathrm{d}\right)$. Steroid resistance was defined as the persistence of proteinuria after a 4-week course of full-dose prednisolone. Steroid dependency was defined as having two consecutive relapses during steroid treatment or within 2 weeks of steroid withdrawal, while "frequent relapsers" were defined as having four or more relapses within a 12-month period. Patients with poor compliance and not on regular follow-up, as well as the infrequent-relapser patients, were excluded. All patients underwent a complete physical examination by an experienced pediatrician. A comparable number of healthy children $(n=56)$, with the same ethnic background, were included as controls. They were evaluated by a trained pediatrician to ensure the absence of any renal disease. They were mostly selected from among patients visiting the hospital's Emergency Department for minor illnesses.

All patients and controls were analyzed for blood urea, serum creatinine, total protein, and albumin levels, as well as a complete lipid profile including serum cholesterol. Urine protein: creatinine ratio was also determined for all the study subjects. Ethical approval was obtained from the Health Sciences Center's Committee for the Protection of Human Subjects in Research as well as the Ministry of Health's Ethics Committee. Written informed consent was obtained from caregivers of both patients and controls as per guidelines of the committees.

\section{Collection and processing of samples}

Approximately 5-8 $\mathrm{mL}$ of blood was collected from all the study subjects in appropriate tubes for subsequent laboratory analyses. Serum was isolated by centrifugation and was used for the biochemical analyses. For genotyping, the blood was collected in tubes containing the anticoagulant EDTA. Total genomic DNA was isolated from all samples by using a standard method. ${ }^{13}$

\section{Genotyping of VDR-Taql and -Apal polymorphisms}

The g. 59979G $>\mathrm{T}$ or c. $1025-49 \mathrm{G}>\mathrm{T}($ Apa $\mathrm{IG} \rightarrow \mathrm{T})$ and g.60058T $>\mathrm{C}$ or c.1056T $>\mathrm{C}($ Taq $\mathrm{IT} \rightarrow \mathrm{C})$ polymorphic sites of the $V D R$ gene (GI: 7421) were analyzed by the polymerase chain reaction (PCR)-RFLP method. ${ }^{14,15}$ A 740 bp fragment was amplified using the primers described earlier. ${ }^{14}$ The PCR mixture contained $100 \mathrm{ng}$ DNA template, $0.18 \mathrm{mM} / \mathrm{L}$ of each primer, $2.2 \mathrm{mM} \mathrm{MgCl}_{2}, 0.2 \mathrm{mM}$ deoxynucleotide triphosphates, and 0.8 U AmpliTaq DNA polymerase (Applied Biosystems, Thermo Fisher Scientific, Waltham, MA, USA). The PCR conditions used were as follows: $94^{\circ} \mathrm{C}$ for $5 \mathrm{~min}-$ utes; 30 cycles consisting of 1 minute at $94^{\circ} \mathrm{C}, 1$ minute at $60^{\circ} \mathrm{C}$, and 90 seconds at $72^{\circ} \mathrm{C}$, followed by an extension step for 10 minutes at $72^{\circ} \mathrm{C}$. The PCR product was digested with 5 $\mathrm{U}$ ApaI (New England BioLabs, Boston, MA, USA) at $25^{\circ} \mathrm{C}$ overnight. The products of restriction enzyme cleavage were analyzed on $2 \%$ agarose gels and were visualized under UV light after staining with ethidium bromide. Alleles ' $G$ ' and ' $T$ ' were assigned based on the presence of a $740 \mathrm{bp}$ (uncleaved) fragment and the $528 \mathrm{bp}$ and $210 \mathrm{bp}$ (cleaved) fragments, respectively (Figure 1). The same PCR product was digested with restriction enzyme TaqI (New England BioLabs) at $65^{\circ} \mathrm{C}$ for 75 minutes to detect the TaqI polymorphism. ${ }^{14}$ The products of restriction enzyme digestion were analyzed on 


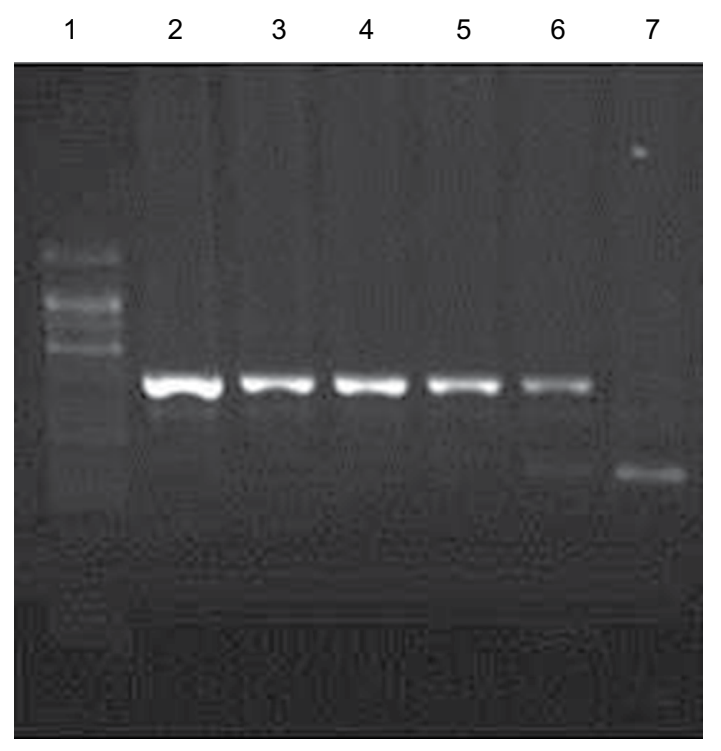

Figure I Determination of genotypes for VDR-Apal polymorphism by using PCRRFLP method.

Notes: Lane I, $M_{r}$ size markers; lane 2, uncleaved PCR product (740 bP); lanes 3-5, Apal cleavage pattern of PCR samples from subjects with TT genotype; lane 6, Apal-cleaved PCR products from a subject with GT genotype; lane 7, Apal-cleaved PCR product from a subject with GG genotype. The products were analyzed on $2 \%$ agarose gels and visualized under UV light after staining with ethidium bromide. Abbreviations: PCR, polymerase chain reaction; RFLP, restriction fragment length polymorphism; VDR, vitamin D receptor.

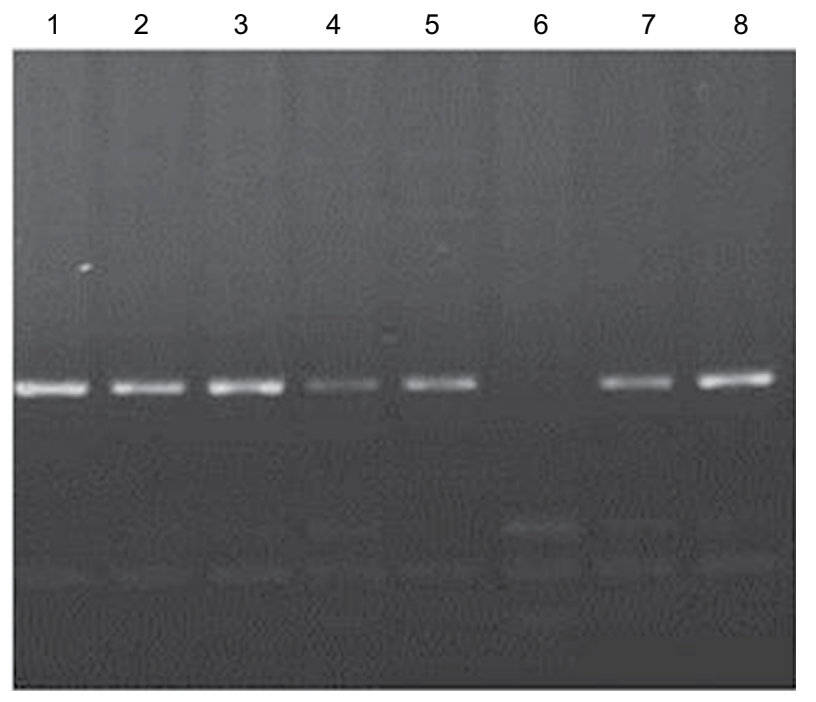

Figure 2 Determination of genotypes for VDR-Taql polymorphism by using PCRRFLP method.

Notes: Lanes I, 5, and 8 show Taql cleavage pattern of samples from subjects with TT genotype; lanes $2-4$ and 7 show the Taql-cleaved PCR product from subjects with TC genotype; lane 6 shows the Taql-cleaved PCR products obtained from a subject with CC genotype. The products were analyzed on $2 \%$ agarose gels and visualized under UV light after staining with ethidium bromide.

$2 \%$ agarose gels and visualized under UV following staining with ethidium bromide. The allele ' $\mathrm{T}$ ' was associated with the presence of a $495 \mathrm{bp}$ fragment, while allele ' $\mathrm{C}$ ' was assigned in the presence of $251 \mathrm{bp}$ and $201 \mathrm{bp}$ fragments (Figure 2). ${ }^{14,15}$

Statistical analysis was conducted using SPSS-IBM software version 21 (IBM Corporation, Armonk, NY, USA).
The chi-square test was used to compare groups and frequencies of $V D R$ genotypes, and Fisher's exact test was used for small-sized groups.

\section{Results}

A total of 78 Kuwaiti children (52 males and 26 females) with a confirmed diagnosis of INS were included in this study. Their ages ranged from 13 months to 12 years, with a mean of $6.5 \pm 3.1$ years. They were categorized according to steroid responsiveness into either steroid-sensitive (SS: 62 patients) or steroid-resistant (SR: 16 patients) groups. Biopsy-proven histological diagnosis of minimal-change nephrotic syndrome (MCNS) was documented in 32 patients in the SS group for steroid dependency. Focal segmental glomerulosclerosis (FSGS) was histologically proven in 13 of the 16 patients with steroid resistance. Of the other three SR patients, MCNS was found in two and membranous glomerulonephritis in one patient. Hypertension was noted in nine patients at diagnosis and in additional seven patients after initiation of prednisolone treatment. None of the steroid responders developed steroid resistance during the course of the disease, whereas five of the SR patients showed partial remission later on during the course of the disease. Only three patients of the FSGS group developed end-stage renal disease during the study period and three patients had chronic kidney disease at the end of the study. All 78 patients received prednisolone as a first-line therapy, while 58 patients required a second-line therapy with either cyclophosphamide $(\mathrm{n}=42)$ or calcineurin inhibitors $(\mathrm{n}=28)$, in addition to methylprednisolone pulse therapy when indicated. Patients were followed up for a mean period of 39 months (range: 6-72 months). Table 1 summarizes the demographic and laboratory data on INS patients compared to the controls.

The results of $V D R$ genotyping in terms of Taq I polymorphism are presented in Table 2. The TT genotype was detected in $41 \%$ of the INS patients compared to $42 \%$ of the controls ( $P=0.816$ ). The heterozygous TC genotype was detected in $33 \%$ of INS patients compared to $46 \%$ of the controls $(P=0.462)$. The CC genotype was detected in $25.6 \%$ of INS patients and $21 \%$ of the controls $(P=0.719)$. The $\mathrm{C}$-allele frequency, in its homozygous and heterozygous forms, was $71 \%$ in INS patients compared to $63 \%$ in the controls $(P=0.342)$.

No significant difference was detected for all the three genotypes in terms of the $V D R-A p a \mathrm{I}$ polymorphism in INS patients compared to the controls $(P=0.76, P=0.207$, and $P=0.364$, respectively, for GG, GT, and TT genotypes). The T-allele frequency, in its homozygous and heterozygous forms, was $90 \%$ in INS patients compared to $93 \%$ in the controls $(P=0.076$; Table 2). 
Table I Clinical and laboratory data of controls and patients with INS

\begin{tabular}{|c|c|c|c|c|c|}
\hline & \multicolumn{2}{|c|}{ INS patients $(\mathrm{n}=\mathbf{7 8})$} & \multirow[t]{2}{*}{$P$-value } & \multirow[t]{2}{*}{ Controls $(n=56)$} & \multirow[t]{2}{*}{ Normal range } \\
\hline & SS $(n=62)$ & SR $(n=16)$ & & & \\
\hline Mean age, years & $5.2 \pm 4.1$ & $9.4 \pm 1.5$ & $<0.0002$ & $7.8 \pm 2.3$ & \\
\hline \multicolumn{6}{|l|}{ Sex } \\
\hline Male & 39 & 13 & & 30 & \\
\hline Female & 23 & 3 & & 26 & \\
\hline Mean serum creatinine, $\mu \mathrm{mol} / \mathrm{L}$ & $53 \pm 19$ & $91 \pm 18$ & $<0.000$ I & $58 \pm 10$ & $(15-88)$ \\
\hline Mean blood urea, $\mathrm{mmol} / \mathrm{L}$ & $5.6 \pm 2.1$ & $8.2 \pm 3.4$ & $<0.0001$ & $4.2 \pm 3.1$ & $(2.5-6.0)$ \\
\hline Mean serum protein, g/L & $59 \pm 3$ & $24 \pm 4$ & $<0.000$ I & $67 \pm 3$ & $(68-80)$ \\
\hline Mean serum albumin, $g / L$ & $29 \pm 5$ & $18 \pm 7$ & $<0.0001$ & $37 \pm 7$ & $(35-45)$ \\
\hline Mean serum cholesterol, $\mathrm{mmol} / \mathrm{L}$ & $5.8 \pm 0.6$ & $6.9 \pm 1.3$ & $<0.0002$ & $3.3 \pm 0.36$ & $(3.1-5.2)$ \\
\hline Mean UP:Cr ratio, mg/mg & $3.3 \pm 0.6$ & $5.6 \pm 1.4$ & $<0.0001$ & $0 \pm 0.09$ & $(\leq 0.2)$ \\
\hline
\end{tabular}

Notes: Data presented as mean \pm standard deviation. $P$-values are significant if $\leq 0.05$.

Abbreviations: INS, idiopathic nephrotic syndrome; SR, steroid resistant; SS, steroid sensitive; UP:Cr, urinary protein:creatinine ratio.

Table 2 Incidence of VDR gene Taql and Apal polymorphism genotypes in children with INS and controls

\begin{tabular}{llll}
\hline Genotype/alleles & INS (\%) & Controls (\%) & P-value* \\
\cline { 2 - 3 } & $\mathbf{( n = 7 8 )}$ & $\mathbf{( n = 5 6 )}$ & \\
\hline Taql genotype & & & \\
TT & $32(41.5)$ & $21(42)$ & 0.816 \\
TC & $26(33.3)$ & $23(46)$ & 0.462 \\
CC & $20(25.6)$ & $12(21.4)$ & 0.719 \\
Subjects with at least one & $56(71.4)$ & $35(63)$ & 0.342 \\
C-allele & & & \\
Apal genotype & & & \\
GG & $8(10.3)$ & $4(7.2)$ & 0.760 \\
GT & $32(41.0)$ & $30(54.5)$ & 0.207 \\
TT & $38(48.7)$ & $22(39.3)$ & 0.364 \\
Subjects with at least one & $70(89.7)$ & $52(92.8)$ & 0.760 \\
T-allele & & & \\
\hline
\end{tabular}

Note: $* P$-values are significant if $\leq 0.05$.

Abbreviations: INS, idiopathic nephrotic syndrome; VDR, vitamin D receptor.

When the INS patients were subdivided according to steroid responsiveness, no significant statistical difference was found in allele frequencies between the SS and SR subgroups when compared with each other, nor when compared to controls.

\section{Discussion}

VDR is a member of the steroid/thyroid hormone receptor family through which the action of the active form of vitamin D is mediated. ${ }^{16,17}$ VDR binds to the active form of intracellular vitamin $\mathrm{D}$ (calcitriol or 1,25-dihydroxy D3) to form a molecule that interacts with the nuclei of the target cells to produce various biological effects, such as immunity, growth, bone mineralization, and differentiation of many cells, as well as playing different functions in different body organs, such as muscles/vessels. ${ }^{2}, 18$ The $V D R$ gene maps to the locus 12q12-q14 and comprises eleven exons that span $\sim 75 \mathrm{~kb}$. The $5^{\prime}$ noncoding end of the gene includes regions of exons $1 \mathrm{~A}, 1 \mathrm{~B}$, and $1 \mathrm{C} .{ }^{1}$ The translated gene product (protein) is encoded by exons $2-9$. Exons $7-9$ play a critical role in binding to vitamin D. Allelic variations in $V D R$ are involved in their function, suggesting in turn that allelic variations in $V D R$ cause functional differences in the potency of 1,25-dihydroxy D3 as an immunosuppressive hormone. ${ }^{19} V D R$ gene polymorphism (including TaqI and ApaI genotypes) is known to be genetically determined and affected by ethnicity. Our study is considered novel as it is the first of its kind reporting this polymorphism in INS Arab patients from the Middle East region. Many previous studies on the effect of $V D R$ gene polymorphism on renal diseases showed conflicting results. ${ }^{9,11,12}$ No effects of the different $V D R$ polymorphic genotypes on both chronic kidney disease and end-stage renal disease were previously documented, ${ }^{20-25}$ whereas studies on systemic lupus erythematosus nephritis, including secondary nephrotic syndrome with or without renal dysfunction, reported an association of renal involvement with the bb genotype of BsmI polymorphism, which is a common single-nucleotide polymorphism of the $V D R$ gene. ${ }^{19}$ INS has been widely considered to be a primary immune disease associated with immune regulatory imbalance between Th1 and Th2 cytokines, which are thought to play major roles in the pathogenesis and progression of the disease.${ }^{10,26-28}$ On the other hand, the important role of VDR gene polymorphism in INS could be mediated through its direct effect on the function and potency of 1,25-dihydroxy D3, which is considered an immune suppressor hormone that negatively regulates the production of different cytokines and downregulation of the immune system. ${ }^{19}$ Reports on $V D R$ gene polymorphism in children with INS are scarce. The only report we could find was by Jafar et al ${ }^{29}$ who reported significant difference in the frequency of ApaI polymorphic 
genotype in INS Indian patients of East Asian origin. In the same study, no difference was reported in the TaqI genotype frequency in the same patients compared to controls. In our patients, we found no association of the two polymorphic genotypes with INS. The fact that the ethnic and genetic background of the Arab race differs from that of the East Asian population might easily explain the difference in the results of the two studies. Moreover, we did not have any previous data about the common $V D R$ polymorphic genotypes in our general population, which might not be reflected by the relatively small number of controls we used. The other unique aspect of our study was exploring the association of $V D R$ polymorphism (TaqI and Apal) with the clinical pattern of INS in terms of steroid responsiveness, which has not been previously reported. We could not elicit any differences in $V D R$ genotype frequency patterns in both SS and SR groups. This was an unexpected finding knowing the immune-modulating and suppressive effect of vitamin D3, which is expected to be synergistic to steroid effects in INS.

\section{Conclusion}

Our data do not support $V D R$ gene polymorphisms (ApaI and $\operatorname{Ta} \mathrm{I}$ ) as being genetic determinants of susceptibility to INS. No association between $V D R$ gene polymorphisms and steroid responsive could be elicited.

\section{Acknowledgments}

We thank the study subjects and their families for participation in this study. The assistance of Mrs Asiya Tasneem in statistical analysis is thankfully acknowledged. The results presented in this paper have not been published previously in whole or in part.

\section{Disclosure}

The authors report no conflicts of interest in this work.

\section{References}

1. Byers SW, Rowlands T, Beildeck M, Bong YS. Mechanism of action of Vitamin D and the Vitamin D receptor in colorectal cancer prevention and treatment. Rev Endocr Metab Disord. 2012;13(1):31-38.

2. Bikle DD. Vitamin D metabolism, mechanism of action, and clinical applications. Chem Biol. 2014;21(3):319-329.

3. Haussler MR, Whitfield GK, Haussler CA, et al. The nuclear vitamin D receptor: biological and molecular regulatory properties revealed. J Bone Miner Res. 1998;13(3):325-349.

4. Uitterlinden AG, Fang Y, van Meurs JB, van Leeuwen H, Pols HA. Vitamin D receptor gene polymorphism in relation to Vitamin D related disease states. J Steroid Biochem Mol Biol. 2004;89-90(1-5): 187-193.

5. Melhus H, Kindmark A, Amér S, Wilén B, Lindh E, Ljunghall S. Vitamin D receptors genotype in osteoporosis. Lancet. 1994;344(8927):949-950.

6. Gunes S, Bilen CY, Kara N, Asci R, Bagci H, Yilmaz AF. Vitamin D receptor gene polymorphism in patients with urolithiasis. Urol Res. 2006; 34(1):47-52.
7. Lin NU, Malloy PJ, Sakati N, al-Ashwal A, Feldman D. A novel mutation in the deoxyribonucleic acid-binding domain of the vitamin D receptor causes hereditary 1,25-dihydroxyvitamin D-resistant rickets. J Clin Endocrinol Metab. 1996;81(7):2564-2569.

8. Seyhan S, Yavascaoglu I, Kilicarslan H, Dogan HS, Kordan Y. Association of vitamin D receptor gene Taq I polymorphism with recurrent urolithiasis in children. Int J Urol. 2007;14(12):1060-1062.

9. CooperJD, SmythDJ, WalkerNM, etal. Inherited variation in VitaminD gene is associated with predisposition to autoimmune disease type 1 diabetes. Diabetes. 2011;60(5):1624-1631.

10. Mathieson PW. Cytokine polymorphisms and nephrotic syndrome. Clin Sci. 2002;102(5):513-514.

11. Morrison NA, Qi JC, Tokita A, et al. Prediction of bone density from vitamin D receptor alleles. Nature. 1994;367(6460):284-287.

12. Tokita A, Matsumoto H, Morrison NA, et al. Vitamin D receptor alleles bone mineral density and turnover in premenopausal Japanese women. J Bone Miner Res. 1996;11(7):1003-1009.

13. Sambrook J, Fritsch EF, Maniatis T. Molecular Cloning - A Laboratory Manual. 2nd ed. New York, NY: Cold Spring Harbor Laboratory; 1989.

14. Yavuz DG, Keskin L, Kıyıc S, et al. Vitamin D receptor gene BsmI, FokI, ApaI, TaqI polymorphisms and bone mineral density in a group of Turkish type 1 diabetes patients. Acta Diabetol. 2011;48(4):329-336.

15. Dilmec F, Uzer E, Akkafa F, Kose E, van Kuilenburg AB. Detection of VDR gene ApaI and TaqI polymorphisms in patients with type 2 diabetes mellitus using PCR-RFLP method in a Turkish population. J Diabetes Complications. 2010;24(3):186-191.

16. Speer G, Cseh K, Winkler G, et al. Vitamin D and estrogen receptor gene polymorphisms in type 2 diabetes mellitus and in android type obesity. Eur J Endocrinol. 2001;144(4):385-389.

17. Calle C, Maestro B, Garcia-Arencibia M. Genomic actions of 1,25-dihydroxyvitamin D3 on insulin receptor gene expression, insulin receptor number and insulin activity in the kidney, liver and adipose tissue of streptozotocin-induced diabetic rats. BMC Mol Biol. 2008;9:65.

18. Jones G, Strugnell SA, DeLuca HF. Current understanding of the molecular actions of vitamin D. Physiol Rev. 1998;78(4):1193-1231.

19. Ozaki Y, Nomura S, Nagahama M, Yoshimura C, Kagawa H, Fukuhara S. Vitamin-D receptor genotype and renal disorder in Japanese patients with systemic lupus erythematosis. Nephron. 2000;85(1):86-91.

20. Tripathi G, Sharma R, Sharma RK, Gupta SK, Sankhwar SN, Agrawal S. Vitamin D receptor genetic variants among patients with end-stage renal disease. Ren Fail. 2010;32(8):969-977.

21. de Souza CM, Braosi AP, Luczyszyn SM, et al. Association between vitamin $\mathrm{D}$ receptor gene polymorphisms and susceptibility to chronic kidney disease and periodontitis. Blood Purif. 2007;25(5-6):411-419.

22. Santoro D, Caccamo D, Gagliostro G, et al. Vitamin D metabolism and activity as well as genetic variants of the vitamin D receptor (VDR) in chronic kidney disease patients. J Nephrol. 2013;26(4):636-644.

23. Zhou TB, Jiang ZP, Huang MF, et al. Association of vitamin D receptor FokI (rs2228570), TaqI (rs 731236) and Apal (rs7975232) gene polymorphism with the risk of chronic kidney disease. J Recept Signal Transduct Res. 2015;35:58-62.

24. Mao S, Huang S. Lack of an association between vitamin D receptor BsmI gene polymorphism and the risk of end-stage renal disease: a meta-analysis. Intern Med. 2013;52(21):2423-2430.

25. Yang L, Wu L, Fan Y, Ma J. Associations among four polymorphisms (BsmI, FokI, TaqI and ApaI) of vitamin D receptor gene and end-stage renal disease: a meta-analysis. Arch Med Res. 2015;46(1):1-7.

26. Cho BS, Yoon SR, Jang JY, Pyun KH, Lee CE. Up-regulation of interleukin-4 and CD23/FceRII in minimal change nephrotic syndrome. Pediatr Nephrol. 1999;13(3):199-204.

27. Noronha IL, Niemir Z, Stein H, Waldherr R. Cytokines and growth factors in renal disease. Nephrol Dial Transplant. 1995;10(6):775-786.

28. Tenbrock K, Schubert A, Stapenhorst L, et al. Type-I IgE receptor, interleukin-4 receptor and interleukin-13 polymorphism in children with nephrotic syndrome. Clin Sci. 2002;102(5):507-512.

29. Jafar T, Tripathi G, Mehndi AA, et al. Vitamin D receptor gene polymorphism in Indian children with idiopathic nephrotic syndrome. Int J Hum Genet. 2009;9:49-55. 
The International Journal of Nephrology and Renovascular Disease is an international, peer-reviewed open access journal focusing on the pathophysiology of the kidney and vascular supply. Epidemiology, screening, diagnosis, and treatment interventions are covered as well as basic science, biochemical and immunological studies. The manuscript management system is completely online and includes a very quick and fair peer-review system, which is all easy to use. Visit http://www. dovepress.com/testimonials.php to read real quotes from published authors.

Submit your manuscript here: https://www.dovepress.com/international-journal-of-nephrology-and-renovascular-disease-journal 